\title{
The importance of architecture education for disaster mitigation
}

\author{
F. Özdoğan \& D. Güney \\ Yildiz Technical University, Turkey
}

\begin{abstract}
Natural disasters such as forest fires, oil spills, earthquakes and floods are a source of high economic, environmental and human impact. Every year, thousands of human lives are lost, millions of people bear the destruction of their homes and an invaluable economic harm is made. It has been estimated that a new big disaster arises every three days, whereas local and regional authorities must manage the thousands of emergencies that take place every year. Turkey is potentially an extremely hazardous place due to its geological state, topographic position and climate. Turkey is one of those countries that frequently experiences different crises such as natural disasters, terrorist attacks, and immigration caused by war and instabilities from neighboring countries. Turkey is also located on the AlpHimalayan Fold Belt with 99 percent of the population, 96 percent of industrial areas, and 75 percent of the power stations in Turkey situated in places accepted as seismically risky. Thus, Turkey is economically vulnerable in terms of earthquake risk; for example, the financial impact on the Turkish economy from the Kocaeli earthquake in 1999 was estimated at $\$ 9$ to $\$ 13$ billion. Architects play important role in disaster mitigation and recovery after hazard events. Architectural design might prevent or decrease destructive consequences of disasters on structures. However, architect must have enough background for disaster mitigation. This can be succeeded during BSc education of architects. As part of the disaster preparation of architects, they must be fully aware of their responsibilities and liaison with relevant disciplines must be defined and properly organized. In this study, architect education system in Turkey is examined especially courses during undergraduate education are analyzed as qualitative and quantitative point of view. Collected data is analyzed and compared with developed and leading countries in disaster management. According to analysis
\end{abstract}


results, proposals will be prepared for a better disaster management and mitigation strategy.

Keywords: natural disasters, mitigation, architectural education, damage, awareness, preparedness.

\section{Introduction}

Natural disasters such as earthquakes, landslides, forest fires, hurricanes, oil spills, and floods are a source of high economic, environmental and human impact. Every year, thousands of human lives are lost, millions of people bear the destruction of their homes and an invaluable economic harm is made. It has been estimated that a new big disaster arises every three days, whereas local and regional authorities must manage the thousands of emergencies that take place every year [1]. These two definitions encompass both man-made and natural disasters including hurricanes, war, floods, civil disturbances and riots, nuclear accidents, landslides, economic depression or disinvestment, plane crashes, and even some urban renewal projects. In a more basic sense, a disaster is an event that causes destruction to the built environment - the places in which humans live, work, and recreate. Just as quickly as people build roads, buildings, and parks, there are forces such as wind, hail, economics, and political conflicts that destroy them. Obviously, emergency management focuses on saving human lives and decreasing economic losses. Nowadays, these objectives are reachable due to the technological revolution that has taken place during the recent years in research areas like computing, telecommunications, computer networks, remote sensing and global positioning. In particular, the appearance of the sensor web enables the sharing of a wide variety of observations from spatially referenced sensors into a distributed computing network [2]. As a result of the integration of these technologies, quick and automatic alert and characterization of disasters is now achievable. The lack of preventive planning and design - both before the disaster and afterward - is a critical problem with which the design world has only slowly been facing. Following the Indian Ocean tsunami in 2004, which killed more than 200,000 people, the first questions were asked about the role and responsibility of architects in disaster risk management. A succession of disasters like the 2008 earthquake in Sichuan province, China, and the 2010 earthquake near Port-auPrince, Haiti, have offered urgent reminders that professional architects - whether in the developing or developed world - are generally absent from efforts to protect people from disaster. They have had no sustained role in shaping policy or leading best practices in disaster prevention, mitigation, and recovery. There is still no career path that prepares students to work as urgentistes - design professionals who intervene at a crucial moment in the recovery process to produce enduring solutions. Architects have been slow to respond to the needs of disaster management but there is a growing engagement. In recent years, a handful of professionals in small agencies or scattered through larger firms have helped to introduce innovative and sustainable building methods, land-use planning, and environmental stewardship to disaster zones. A common ideology has emerged on how to bridge the gap between short-term emergency needs and long-term 
sustainable recovery. In the most successful cases, three of which are presented here, the project is rooted in the profound belief that the local community is at the center of the process leading to pertinent and sustainable solutions, and that culture and architecture are inseparable allies [3]. Design professionals and the construction industry have a significant role in the health and safety of the environment and in disaster management (Figure 1). Their role includes a range of activities designed to maintain control over emergency situations, providing a framework for helping those who are at risk to avoid or recover from the impact of the disaster (Kelly, Limitations to the Use of Military Resources for Foreign Disaster Assistance, 1996). FEMA recognizes both as unfilled roles, stating "the literature on natural hazard mitigation directed toward the architectural profession is scarce in spite of the fact that architects can make a significant contribution to hazard risk reduction" [4]. As a first priority, the American Institute of Architects has been advocating for architects to engage with local building departments and state emergency management agencies to perform building safety assessments when needed. This community engagement reduces the need for temporary housing and prevents further injury or loss of life by ensuring that structures are safe to occupy.

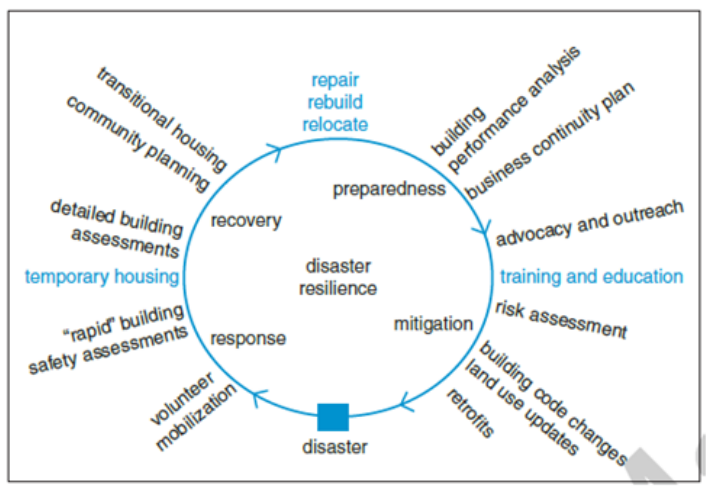

Figure 1: Disaster resilience cycle and the role of the architect [5].

Communities can prepare themselves for potential disasters and mitigate or reduce the impact of hazards so that they will not have to rebuild their homes and businesses. When risks are addressed ahead of time, the potential for damage will decrease. As expressed by FEMA, "mitigation has long been perceived and practiced as an essential tool for helping to save lives, reduce property damage, and decrease the money spent on disaster recovery efforts." Informed and trained architects can be advocates for increased public education and awareness by conveying the risks owners face and demonstrating how those risks can be reduced through specific building mitigation methods [5].

Architectural education has a long experience in Turkey. Formal education in Western terms goes to the beginning of the 19th century, while the presence of an architectural education goes back to the 15 th century. After the proclamation of 
the Republic, architectural education has shown an ever improving line. The schools of architecture have always been the focus of prevailing architectural ideologies and after 1960 the social developments in the country have motivated the new searches in architecture. Due to the research done in the universities, these institutions today function on the leadership role of innovations in building technology. Turkey with her almost 15,000 architects, is a pool for architectural education and building construction for the Middle East. As architectural education has always been developed in accordance with the architectural movements, it is unavoidable to briefly review the architectural developments in the country. Today there are nine Faculties of Architecture in different Universities of Turkey. Some of them are still in the foundation stage. Istanbul Technical University, Mimar Sinan University (former D.G.S.A.) and M.E.T.U. retain their influential positions [6].

\section{Vulnerability of Turkey to natural disaster}

Turkey is in a region that is politically vulnerable and prone to natural disasters. Statistically, a large-scale disaster happens every seven to eight years (Table 1) in Turkey, disasters are both natural and human made, causing serious disruption of normal daily life, causing widespread human, material or environmental losses that exceed the ability of the affected populations and the government to cope using its own resources. In general, the country is subjected to earthquakes, floods, landslides, avalanches and forest fires, with earthquakes having by far the greatest impact on population and infrastructure.

Table 1: $\quad$ Summarized table of natural disasters in Turkey from 1900 to 2009.

\begin{tabular}{|l|c|c|c|c|}
\hline \multicolumn{1}{|c|}{ Type of disaster } & No. of events & Killed & Total affected & Damage US\$ \\
\hline Earthquake & 71 & 88.538 & 6.874 .596 & 22.941 .400 \\
\hline Epidemic & 8 & 613 & 204.855 & \\
\hline Extreme temperature & 7 & 100 & 8.450 & 1.000 \\
\hline Flood & 35 & 1.274 & 1.743 .386 & 1.645 .500 \\
\hline Dry mass movement & 1 & 261 & 1.069 & \\
\hline Wet mass movement & 1 & 135 & & \\
\hline Avalanche landslide & 7 & 269 & 13.275 & 26.000 \\
\hline Storm & 9 & 100 & 13.639 & 2.200 \\
\hline Forest fire & 5 & 15 & 1.150 & \\
\hline
\end{tabular}

The long written history of Turkey includes descriptions of many destructive earthquakes during the past thousand years. The earliest earthquake records date back to 411 B.C. There have been nearly 100 earthquakes with magnitudes 7.0 or greater in Turkey. Also 14 earthquakes with casualties more than 10,000 have occurred since 342 A.D. As a result, Turkey ranks high among the countries which have suffered significant losses of life and property due to earthquakes. Over 
80,000 people have lost their lives as a result of 80 big earthquakes that have occurred in Turkey over the last century. The most important events were the earthquakes on 17 August 1999 and 12 November 1999, with magnitude of 7.4 and 7.2 respectively, which took place on the populated and industrial northwestern parts of Turkey. According to official data, the earthquakes caused 18,373 deaths and 48,901 injuries and according to official figures 311,693 residential units and 46,538 business units either collapsed or were lightly to heavily damaged in an area of some $30,000 \mathrm{~km}^{2}$, including eight urban agglomerations and the country's industrial and economic center. Landslides account for over $25 \%$ of Turkey's natural disasters. From 1955 to 2007 landslides affected 4500 settlements and killed 200 people. In this period 65,000 dwelling units were relocated to safer places. Landslides frequently affect inner Anatolia, Eastern Anatolia and particularly the Black Sea regions in Turkey. Floods are among the most frequent and costly natural disasters in Turkey in terms of human suffering and economic losses. Floods account for over $10 \%$ of Turkey's natural disasters. In the period of 1955-2007 there have been 1400 flood occurrences that caused 1400 deaths and collapse of 65,000 dwelling units. In the same period according to the disaster database, 775 rock falls have occurred and have caused 34 deaths and 27,000 house damages. Snow avalanches are frequently observed in eastern and south eastern regions, where snow fall is heavy. Since 1950 there have been 389 snow avalanches which caused 1039 deaths and 5200 house damages.

In the 50s Turkey faced heavy natural disasters: Erzincan Earthquake (1992), Flood in Black Sea Region (1998), Adana- Ceyhan Earthquake (1998), Marmara Earthquake (1999), Hakkari Earthquake (2004) and Sivas Landslide (2005). Direct economic losses due to natural disasters are expected to be $1 \%$ of GDP every year. Losses like decrease on the market, production losses and unemployment are even greater. The probability of economic losses exceeding 11.4 billion US\$ in one year is about $0.5 \%$. This is about $6 \%$ of the country's GDP. The probability of annual losses exceeding 3.5 billion US\$ is about 5\%. After the 1999 two major earthquakes with big impact, the main concepts of a disaster management system have been changed. Many new laws, regulations and other instruments on planning and implementations in all phases of disaster (mitigation, preparedness, response, recovery and rehabilitation) were accepted. But the disaster risk reduction system of Turkey is still mainly centralized. Unlike the central government, local governments are not given any real responsibility with respect to disaster management. Development of standards for public education and community organizations, reaching the public at large, active participation of public, training the trainers and production of training materials has not been considered. Although the educational efforts underway so far are valuable and have reached a large number of people, the current situation can be summarized as a pervasive state of un-preparedness. The educational work done so far focused solely on "what and how to do". Information on earthquakes is presented, nonstructural mitigation is demonstrated, what to do during an earthquake is shown and a trial is made. This focus is certainly important. Yet, clearly another focus is required; which is to find the mechanisms to get the public to take action [8]. 


\section{Disaster preparedness in architectural education}

In order to understand better disaster mitigation system, three leading country and Turkish architectural education system have been analyzed. These leading countries are USA, Japan and Italy. These countries are also having efficient disaster management systems. Undergraduate level architectural education programs are based on university background and their architectural concept. Four famous and institutional architectural departments in USA are examined. They are University of South California, Cornell University, California Polytechnic State University, University of Texas. They have developed their own architectural trends in USA therefore these universities education programs and the relations between education program and disaster management are studied [1]. The total number of the courses, and number of compulsory courses and the contents of the courses have been studied according to those selected universities. Based on content of the courses, the relations between disasters and disaster management concept are investigated and illustrated in Figure 2.

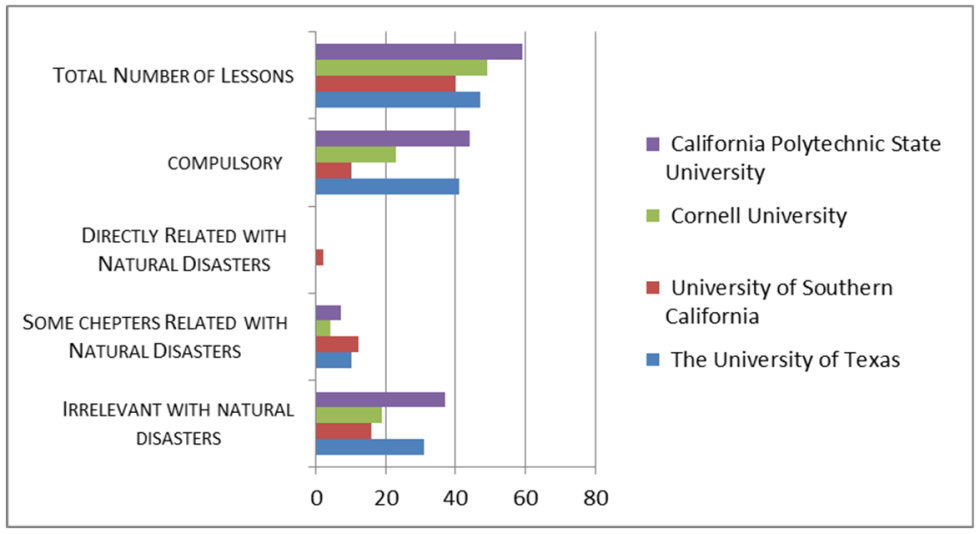

Figure 2: U.S.A architecture schools' curriculum content chart.

Japan has a deep experience for disaster management since they have experienced many types of destructive natural disaster for centuries. Therefore, architectural education system and their content of courses in Japan reflect their background in this field. Based on this disaster management concept, the education of architect in Japan is too difficult and authority for professional architects is based on qualify exams and professional experiences. An ordinary architect student gets enough knowledge and information about disaster management during his/her design studios and other courses. Most of compulsory and elective courses have enough subjects in their content. The first qualify exam after graduation and other grade promotion exams contains disaster mitigation and management topics. Because of special conditions of Japan, architects have to know detailed information about earthquake, tsunami, hurricane, flood resistant design. Four famous and institutional architectural departments in Japan are 
examined. They are Chiba, Kyoto University, Tokyo University, Waseda University. They have institutional background with skilled and experienced academic staff therefore the relations between education program and disaster management are studied for these universities. Based on content of the courses, the relations between disasters and disaster management concept are investigated and illustrated at Figure 3. Compared with US universities, Japan universities have much more courses related with disasters.

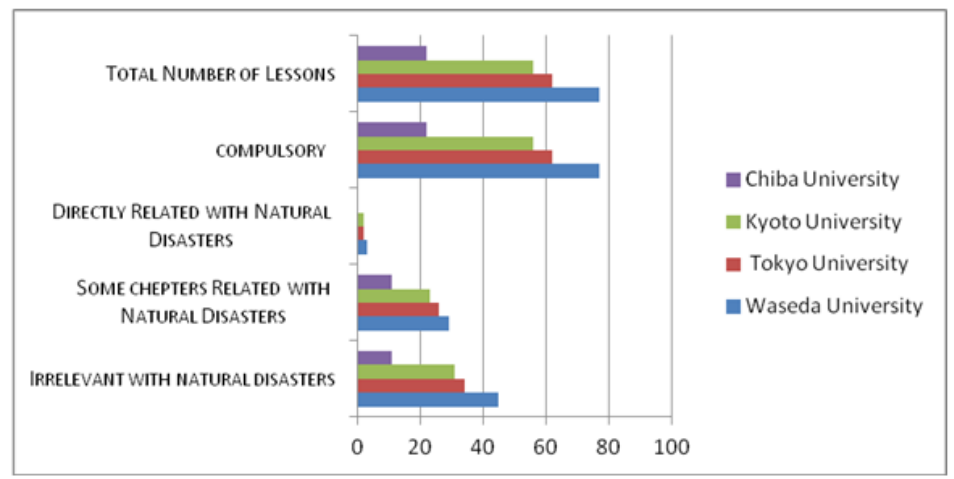

Figure 3: Japan architecture schools' curriculum content chart.

Italy also has a significant background for disaster management and disaster resistant design. They have serious experience against earthquakes, volcano eruptions, landslides, avalanches. Four famous and leading architectural departments in Italy are studied. They are Sapienza Universita di Roma, Universita Degli Studi Firenze, Politecnico di Milano, Politecnico di Bari. According to courses and their contents, it is difficult to find courses directly related with disasters as shown in Figure 4. However partially related (some parts of the content) with disaster courses are satisfactory.

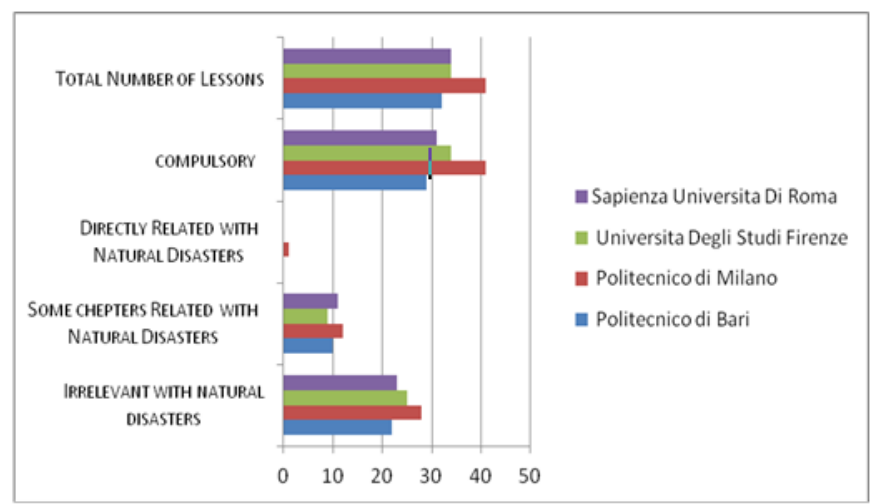

Figure 4: Italian architecture schools' curriculum content chart. 
In Turkey, the architectural education is given at four-year undergraduate and graduate (master and doctorate) levels. On evaluating master and doctorate education separately, graduate education is composed of 21-credit course, seminars, and thesis study. Although the courses change according to the universities, they are mostly elective courses depending on the student's interest and thesis study. In Turkey, architectural education at undergraduate degree is carried out in 67 universities according to the 2012 data of SSPC (OSYM) (OSYM, 2012). In a study made in 2011, this number was determined as 42 . In one-year period, there has been an increase of more than $50 \%$ in the number of architectural departments. In this study 5 leading and famous universities programs are studied. The undergraduate education is 8 semesters and composed of compulsory and optional courses. The proportion of optional course hours was determined as $8 \%$ to all course hours.

1. General Information: Basic Sciences (Mathematics, Computer, Physics, Chemistry, etc.), Social Sciences (Economy, Psychology, Sociology, Anthropology, History, Research Methods, etc.), and Language Sciences (English, Turkish, etc.)

2. Constructional Sciences and technology: Building systems, construction materials, construction physics (lighting and air conditioning)

3. Design Information: Architectural design, indoor design, presentation techniques

4. History, Theory, Culture, and Art: Art history, city history, architecture history and theories, typology, and structure history

5. Environment and City: Urban environment, urban design, historical design, historical environment, protection restoration, natural environment-natural catastrophes, environment control, landscape, ecology, and topography

6. Vocational Studies, Management, and Economy: Constructional economy, management, and laws. The rates of these courses in the program according to the course hours are as follows.

The studied leading universities are Middle East Technical University (METU), Istanbul Technical University (ITU), Y1ldı Technical University (YTU), Karadeniz Technical University (KTU) and Dokuz Eylül University (DEU) since their programs clearly reflect architectural education standards in Turkey [1] According to courses and their contents of studied universities, it is difficult to find courses directly related with disasters as shown in Figure 5. In addition to this partially related (some parts of the content) with disaster courses are very limited.

The comparison graphic between country averages is given in Figure 6. As shown in the graphic, Japan has the best value for courses directly or partially related with disasters. This result shows Japanese disaster management and disaster resistant design background. However Turkish ratio is the lowest for courses directly or partially related with disasters. 


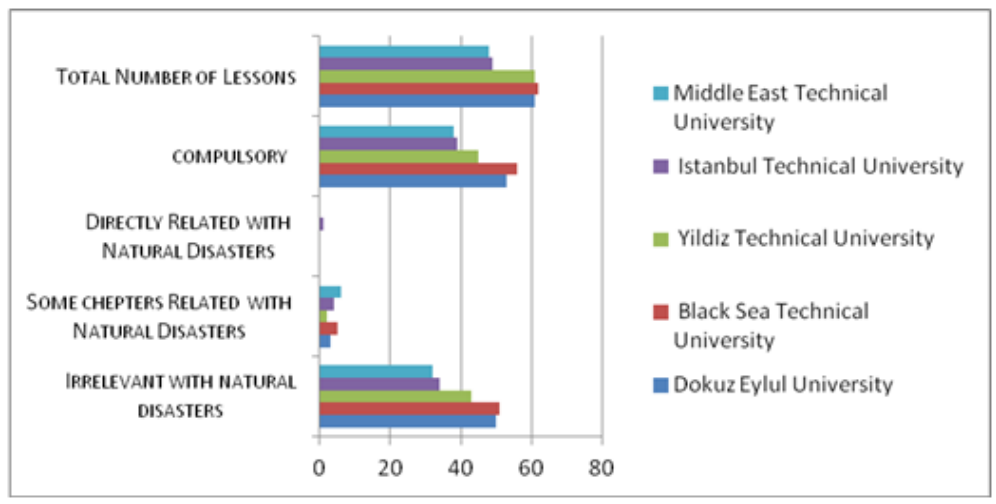

Figure 5: Turkey architecture schools' curriculum content chart.

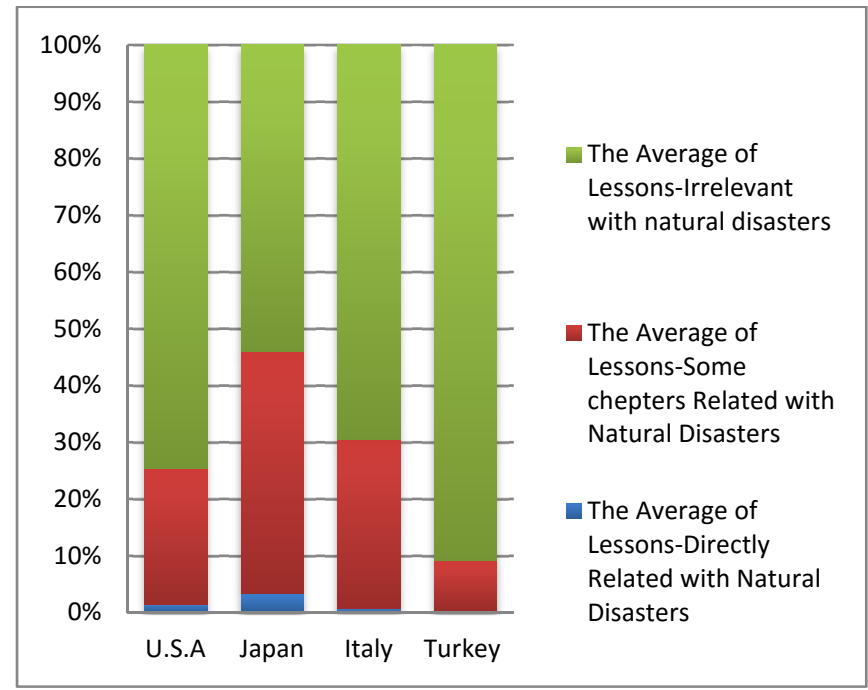

Figure 6: Comparison chart of different countries' architecture schools' curriculum content.

\section{Survey study}

A survey was prepared in order to understand and measure evaluation of disaster preparedness of students of architecture. Survey for students contains 27 questions. This survey was prepared, applied and evaluated as execution part of MSc thesis study. Survey for students has 27 evaluation questions and 59 architectural students were surveyed. This survey has three basic parts. First part of the survey based on personal and professional point of view, second part of the survey based on evaluation of under graduation education, third part of the survey 
Table 2: $\quad$ Survey result of bachelor student participations.

\begin{tabular}{|c|c|c|c|c|c|}
\hline & 1 & 2 & 3 & 4 & 5 \\
\hline $\begin{array}{l}\text { I've knowledge about natural disasters' type/ } \\
\text { frequency/effects in Turkey. }\end{array}$ & $0 \%$ & $5 \%$ & $37 \%$ & $51 \%$ & $7 \%$ \\
\hline $\begin{array}{l}\text { Architecture is directly efficient to natural } \\
\text { disaster reduction. }\end{array}$ & $2 \%$ & $3 \%$ & $8 \%$ & $34 \%$ & $53 \%$ \\
\hline $\begin{array}{l}\text { Architecture education contributes me to follow } \\
\text { last news about natural disaster. }\end{array}$ & $2 \%$ & $10 \%$ & $31 \%$ & $37 \%$ & $20 \%$ \\
\hline $\begin{array}{l}\text { Not only archtitects, but also all disciplines are } \\
\text { responsable for building damage caused by } \\
\text { natural disasters. }\end{array}$ & $0 \%$ & $0 \%$ & $0 \%$ & $24 \%$ & $76 \%$ \\
\hline $\begin{array}{l}\text { Earthquake is the only natural disaster where } \\
\text { precautions can be taken. }\end{array}$ & $73 \%$ & $20 \%$ & $3 \%$ & $3 \%$ & $0 \%$ \\
\hline $\begin{array}{l}\text { I may have enough information about buildings } \\
\text { getting over earthquakes with minimum damage }\end{array}$ & $0 \%$ & $8 \%$ & $22 \%$ & $49 \%$ & $20 \%$ \\
\hline $\begin{array}{l}\text { I think architecture curricula are busy and } \\
\text { sufficient enough for professional competence. }\end{array}$ & $5 \%$ & $8 \%$ & $37 \%$ & $34 \%$ & $15 \%$ \\
\hline $\begin{array}{l}\text { I took/will take at least one elective lesson abou } \\
\text { natural disasters. }\end{array}$ & $5 \%$ & $7 \%$ & $24 \%$ & $49 \%$ & $15 \%$ \\
\hline $\begin{array}{l}\text { There isn't enough time for natural disaster in } \\
\text { architecture education because so many other } \\
\text { topics occur during education. }\end{array}$ & $7 \%$ & $12 \%$ & $32 \%$ & $29 \%$ & $20 \%$ \\
\hline $\begin{array}{l}\text { Lecturers of design lessons give ideas on design } \\
\text { against natural disasters' effects. }\end{array}$ & $5 \%$ & $19 \%$ & $36 \%$ & $36 \%$ & $8 \%$ \\
\hline $\begin{array}{l}\text { In design lessons, related regulations, laws abou } \\
\text { dis. reduction are mentioned }\end{array}$ & $12 \%$ & $15 \%$ & $39 \%$ & $32 \%$ & $2 \%$ \\
\hline $\begin{array}{l}\text { Visiting disaster regions with lecturers would } \\
\text { help me to improve awareness on professional } \\
\text { life. }\end{array}$ & $0 \%$ & $2 \%$ & $2 \%$ & $40 \%$ & $56 \%$ \\
\hline $\begin{array}{l}\text { Total period of architecture education is proper } \\
\text { in Turkey. }\end{array}$ & $12 \%$ & $17 \%$ & $37 \%$ & $20 \%$ & $14 \%$ \\
\hline $\begin{array}{l}\text { Professional competence for architecture } \\
\text { (bachelor's degree) is proper in Turkey. }\end{array}$ & $8 \%$ & $17 \%$ & $32 \%$ & $39 \%$ & $3 \%$ \\
\hline $\begin{array}{l}\text { I want to learn and practice the regulations and } \\
\text { laws about natural disaster reduction during my } \\
\text { undergraduate education. }\end{array}$ & $0 \%$ & $3 \%$ & $8 \%$ & $51 \%$ & $37 \%$ \\
\hline $\begin{array}{l}\text { Lessons about natural disasters should be in } \\
\text { master degree curriculum, not in undergraduate. }\end{array}$ & $14 \%$ & $37 \%$ & $32 \%$ & $10 \%$ & $7 \%$ \\
\hline $\begin{array}{l}\text { I would like my lecturer to give advises about } \\
\text { nat. disasters in design lessons. }\end{array}$ & $0 \%$ & $3 \%$ & $3 \%$ & $49 \%$ & $44 \%$ \\
\hline $\begin{array}{l}\text { Laws and regulations about natural disaster } \\
\text { mitigation should be evaluated in design lessons }\end{array}$ & $0 \%$ & $3 \%$ & $17 \%$ & $53 \%$ & $27 \%$ \\
\hline $\begin{array}{l}\text { Lessons with other disciplines would be useful } \\
\text { to learn design criterias of natural disaster } \\
\text { mitigation. }\end{array}$ & $2 \%$ & $2 \%$ & $17 \%$ & $61 \%$ & $19 \%$ \\
\hline $\begin{array}{l}\text { Related lessons with natural disaster should be } \\
\text { increased during undergraduate to mention } \\
\text { natural disasters in studio lessons. }\end{array}$ & $0 \%$ & $3 \%$ & $22 \%$ & $58 \%$ & $17 \%$ \\
\hline
\end{tabular}


Table 2: $\quad$ Continued.

\begin{tabular}{|l|c|c|c|c|c|}
\hline & 1 & 2 & 3 & 4 & 5 \\
\hline $\begin{array}{l}\text { In Turkey, lessons about relationship between } \\
\text { architecture and natural disasters should be give } \\
\text { in undergraduate architecture education. }\end{array}$ & $2 \%$ & $3 \%$ & $22 \%$ & $54 \%$ & $19 \%$ \\
\hline $\begin{array}{l}\text { I think I'll find a chance to work on nat. disaster } \\
\text { mitigation in business life. }\end{array}$ & $2 \%$ & $3 \%$ & $25 \%$ & $58 \%$ & $12 \%$ \\
\hline $\begin{array}{l}\text { In business life, only electrical and mechanical } \\
\text { engineers are reponsible for fire security in a } \\
\text { project. }\end{array}$ & $44 \%$ & $36 \%$ & $12 \%$ & $7 \%$ & $2 \%$ \\
\hline $\begin{array}{l}\text { Only civil engineers are responsable for } \\
\text { earthquake resistance in business life. }\end{array}$ & $53 \%$ & $31 \%$ & $8 \%$ & $7 \%$ & $2 \%$ \\
\hline $\begin{array}{l}\text { I would prefer to learn design precautions of } \\
\text { natural disasters in case of necessity. }\end{array}$ & $20 \%$ & $31 \%$ & $27 \%$ & $19 \%$ & $3 \%$ \\
\hline $\begin{array}{l}\text { I would prefer to learn laws and regulations } \\
\text { about natural disaster mitigation in case of } \\
\text { necessity in business life instead of } \\
\text { undergraduate education. }\end{array}$ & $22 \%$ & $32 \%$ & $15 \%$ & $25 \%$ & $5 \%$ \\
\hline $\begin{array}{l}\text { In business life, my knowladge by means of } \\
\text { undergraduate education will be useful and } \\
\text { enough for me. }\end{array}$ & $2 \%$ & $3 \%$ & $17 \%$ & $54 \%$ & $24 \%$ \\
\hline
\end{tabular}

based on evaluation of expectations for professional life from point of this concept. Participants can answer the questions with totally agree, neutral and disagree. Participants can show their agreement to the survey statements from 1 to 5.1 means totally disagree, 5 means totally agree $(* 1-$ Totally disagree/2-Disagree /3-Neutral/4-Agree/5-Totally agree). The aim of this survey is to measure and learn students' personal evaluations. The content of the survey and results are given in Table 2 [1].

\section{Conclusions}

Turkey's geological, seismic, topographical and climatic characteristics combine to provide a settling for many types of disasters. The last twenty years of major disaster experience have obviously shown us the shortcomings and weaknesses of the disaster management policies and systems that exist in Turkey. Legislations, regulations are the main tools to perform the policies. In Turkey, after the Marmara Earthquake the legislations and were regulations reviewed and revised in order to obtain an "effective disaster management system". As shown in previous chapters, there is a strong relation between education and disaster preparedness and mitigation. Unfortunately, there are currently a few lessons in architecture departments in Turkey include natural disasters, disaster response, disaster management, disaster risk-reduction and development in their undergraduate curriculum. Even though some lessons have natural disasters related subjects, their credits are inadequate to reach desired level. According to the analyses of architectural undergraduate curriculums of various countries which are exposed same natural disasters or pioneer in disaster management, those countries 
universities average rate (related courses credits/total credits) is more than Turkey. Examples from USA, Japan and Italy have highlighted that architecture education has an important role for smooth running disaster mitigation system. Especially Japanese system (details are given before) shows us quality of education system has a serious effect for disaster preparedness and mitigation.

The survey results for professional architects' shows that much more experienced architects for disasters are required. Architects generally aware of importance of disaster preparedness and mitigation during the first 5 years of their professional life. However, the most basic part of this background can give during undergraduate education. The inclusion of the topic to the undergraduate curriculum could offer future architects the tools they need to design well prepared human settlements, against disasters which are resilient to such natural events whilst enhancing their overall academic experience.

Otherwise, even though participants to our study are aware of importance of disasters however both architecture students and architects believes that they don't have enough background and knowledge to work in professional life. Especially students' don't feel ready to get into this subject. In addition to this architects wants to learn design criteria's of disaster resistant settlements.

As a result of this study, a new interdisciplinary field involving both architecture education and disaster management system in Turkey should be developed. Awareness, knowledge, and options for positive action can empower individuals to create resilient sustainable communities.

\section{References}

[1] Ozdogan F., Guney, D., The Role of Architecture Education in Natural Disaster Mitigation, 2nd International Conference on Architecture, Structure and Civil Engineering, (ICASCE'16), London (UK), March 26-27, 2016. Proceedings of ICASCE'16, ISBN 978-93-84422-62-2, http://dx.doi.org/ 10.17758/UR.U0316.

[2] Delin K, Shannon P, 2001, The Sensor Web: A new Instrument Concept. SPIE ${ }^{e e}$ Symposium on Integrated Optics. San José, CA, USA, January 20-26.

[3] Aquilino, M., Gans, D., Cross, R., Galeazzi, F., Palleroni, S., 2011, Solutions Journals, Vol. 2 (5), pp. 43-50.

[4] FEMA 454, Designing for Earthquakes: A Manual for Architects: http://www.fema .gov/library/viewRecord.do?id=2418.

[5] Minnery, Rachel, 2013, The Role of Architects in Disaster Response and Recovery, The Architect's Handbook of Professional Practice, Wiley, pp. 131-142.

[6] Sey, Y., Tapan, M., Architectural Education in Turkey: Past and Present, http://archnet.org/system/publications/contents/3924/original/DPT0429.pdf? 1384777424

[7] EM-DAT (2009) The OFDA/CRED International Disaster Database. http://www.emdat.be/Database/CountryProfile/countryprofile.php

[8] Taymaz M. (2008) Interim national progress report on the implementation of the Hyogo Framework for Action, An HFA Monitor update published by Prevention Web, http:// www.preventionweb.net 